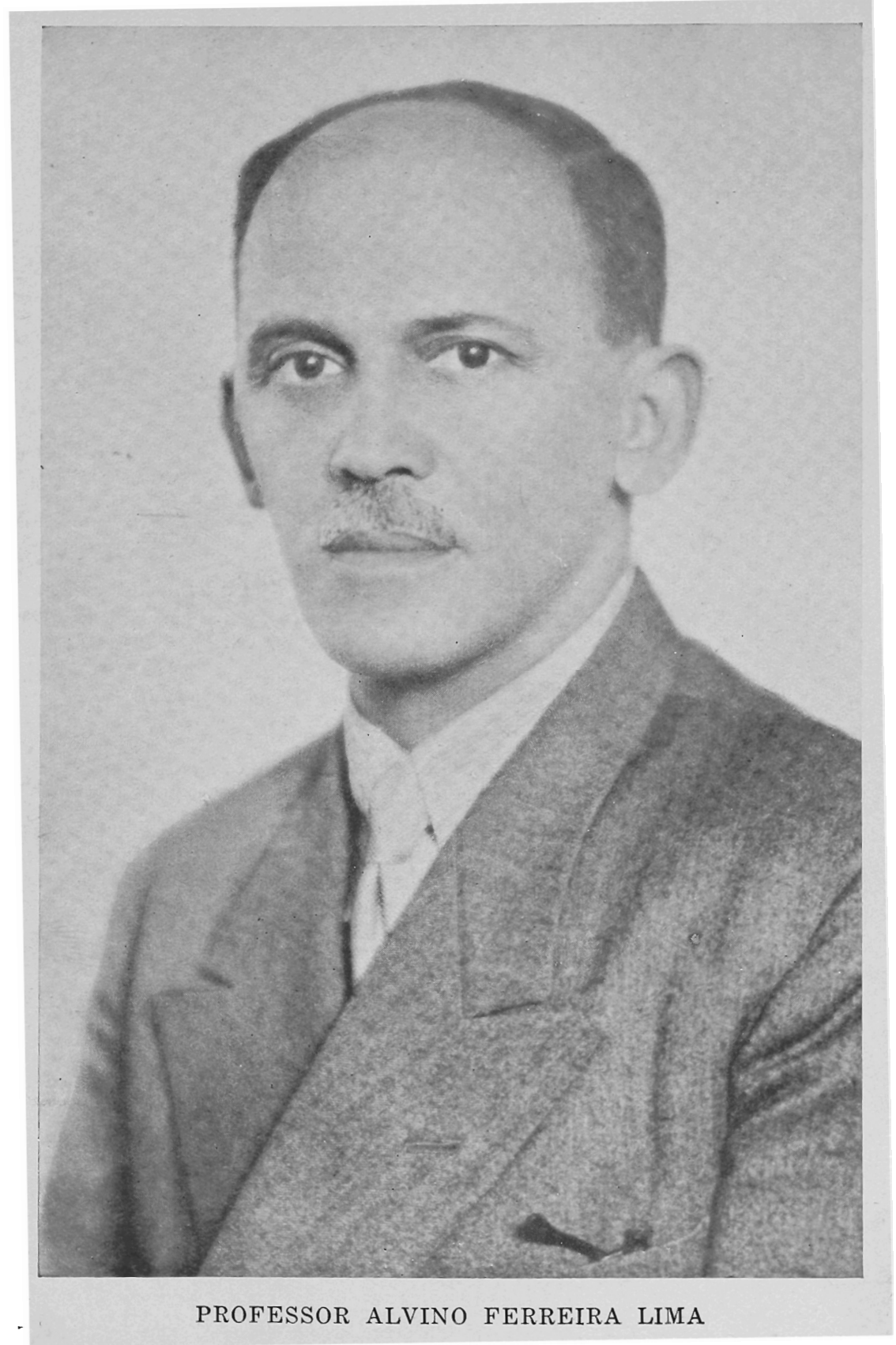




\section{Alvino Ferreira Lima}

roPfessor Catedrático de Direito Civil

Nasceu, o dr. Alvino Ferreira Lima, em 9 de agosto de 1888, em Rosário do Catete, Estado de Sergipe, filho legítimo de Eustáquio Ferreira Lima e dona Etelvina Maria de Lima. Aos quatro anos de idade mudou-se, em companhia de seus progenitores, para o Estado de São Paulo e passou a residir na então vila de Vargem Grande, Comarca de São João da Boa Vista.

Iniciou os estudos de primeiras letras em escolas particulares de Vargem Grande e, posteriormente, em 1889, entrou para o Colégio Azevedo Soares, nesta capital. Em 1900. transferiu-se para o Colégio Rosa, de Pocos de Caldas, Estado de Minas Gerais, e lá se preparou afim de fazer, no antigo Curso da Faculdade de Direito de São Paulo, os primeiros exames parcelados que veiu a concluir, em 1904, no Instituto de Ciências e Letras, desta capital.

Ingressando na Faculdade de Direito em 1904, terminou-o, brilhantemente, em 1908, recebendo, a 1 de dezembro, o grau de bacharel em ciências jurídicas e sociais.

Comecou, em abril de 1909, a exercer a advocacia em Casa Branca, e naquela cidade paulista ocupou, cerca de doze anos, o cargo de lente de matemática da Escola Normal. Ingressando, ali, na politica, foi eleito prefeito municipal, cargo que exerceu em 1922 e 1923, e, no ano seguinte, recebeu a investidura de presidente da câmara municipal.

Em 1925, transferiu-se para esta capital, indo trabalhar em companhia do dr. Antonio Augusto de Covello. 
Fez o seu primeiro concurso de Direito Civil, nesta Faculdade, em agosto de 1936, e foi classificado em segundo logar. Em virtude dessa classificação, recebeu o título de doutor em direito e foi nomeado livre docente da cadeira de direito civil. Durante os anos de 1937 e 1938 lecionou a referida matéria, em substituição ao professor José Augusto Cesar.

Em dezembro de 1938, submeteu-se a novo concurso de direito civil, na vaga daquele saudoso Mestre, e mereceu ser classificado em primeiro logar.

Nomeado professor catedrático de direito civil em 10 de janeiro do corrente ano, tomou posse solene perante a Congregação desta Faculdade. No ato, falou o professor Gabriel José de Rezende Filho, então diretor em exercício, saudando o novo catedrático em nome da Congregação. Respondeu este em discurso de improviso. Ambos os discursos não foram taquigrafados.

\section{OBRAS E TRABALHOS PUBLICADOS}

O professor Alvino Ferreira Lima tem publicado diversos trabalhos jurídicos.

São de sua autoria as seguintes obras:

$$
\begin{aligned}
& 1 \text { - "O direito de retenção e o possuidor de má fé". } \\
& 2 \text { - "Da culpa ao risco" } \\
& 3 \text { - "Estudos de direito civil". }
\end{aligned}
$$

Contam-se, ainda, numerosos esparsos de arrazoados, pareceres, folhetos, etc., na defesa dos direitos dos seus constituintes.

Tem mantido, largamente, colaboração sobre assuntos juridicos na "Revista dos Tribunais" e em diversos jornais de S. Paulo. 